\title{
Influence of organic amendments on phytostabilization of Cd-contaminated soil by Eucalyptus camaldulensis
}

\author{
Weeradej Meeinkuirt $^{\mathrm{a}, *}$, Maleeya Kruatrachue ${ }^{\mathrm{b}}$, John Pichtel $^{\mathrm{c}}$, Theerawut Phusantisampan ${ }^{\mathrm{d}}$, \\ Patompong Saengwilai ${ }^{\mathrm{b}}$ \\ a Mahidol University, Nakhonsawan Campus, Nakhon Sawan 60130 Thailand \\ b Department of Biology, Faculty of Science, Mahidol University, Bangkok 10400 Thailand \\ c Department of Natural Resources and Environmental Management, Ball State University, Muncie, \\ IN 47306, USA \\ ${ }^{d}$ Department of Biotechnology, Faculty of Applied Science, \\ King Mongkut University of Technology North Bangkok, Bangkok 10800 Thailand
}

*Corresponding author, e-mail: phytoplankton8@gmail.com

Received 17 Sep 2015

Accepted 18 Mar 2016

\begin{abstract}
Greenhouse and field experiments were conducted to evaluate the influence of three different organic amendments (cow manure, pig manure, and organic fertilizer) on the Cd phytostabilization potential of Eucalyptus camaldulensis grown on Cd-contaminated soil. The application of all amendments, particularly organic fertilizer, improved plant growth (i.e., height and biomass production) when compared to the control (Cd-contaminated soil alone), in both greenhouse and field experiments. E. camaldulensis treated with organic fertilizer experienced the greatest height $(39 \mathrm{~cm}$ and $3.8 \mathrm{~m})$ and biomass production $(2.0 \mathrm{~g}$ and $3.3 \mathrm{~kg})$ in greenhouse and field experiments, respectively. Plants grown on amended soils had lower $\mathrm{Cd}$ accumulation than those grown on the $\mathrm{Cd}$ soil alone. Among the treatments, organic fertilizer resulted in a translocation factor $<1$ and a bioconcentration factor for the root (BCFR) $>1$, indicating the potential of this species to stabilize $\mathrm{Cd}$ in the roots. The results showed that E. camaldulensis is a promising species for phytostabilization of Cd-contaminated soil. The wood of the mature tree is used in the manufacture of commercial products; given the low Cd uptake by E. camaldulensis, it is feasible to harvest the wood grown on Cd-affected soils for making paper and furniture.
\end{abstract}

KEYWORDS: phytoremediation, excluder plant, pot experiment, field experiment

\section{INTRODUCTION}

Heavy metals are released to the environment via a number of avenues including metal smelting, land application of sewage sludge, and improper disposal to water and land, among others. Common sources of metals to the biosphere include mining and industrial activities. The release of heavy metals to soil and aquatic ecosystems can lead to metal accumulation in the local environment, including food chains ${ }^{1}$.

Cadmium (Cd) is a notoriously toxic metal, as it is hazardous at low concentrations and its accumulation in organisms is linked with a number of nephrological and other diseases ${ }^{2}$. Cadmium has been detected in significant concentrations in soils of the Padaeng zinc mining area (Mae-Sot district, Tak Province, Thailand). Of more immediate importance, however, Cd occurs in soils of agricultural areas adjacent to and downstream of the mines. In the Mae Sot district, cultivation of various crops such as rice, corn, soya beans, garlic, and shallots is a common practice among local villagers as the soils are deep, fertile, and ideal for crop cultivation. Unfortunately, however, high Cd concentrations (range of 3.4-284.0 mg/kg) which are between 1 and 94 times higher than those allowed under the European Community limit of $3 \mathrm{mg} / \mathrm{kg}$, pose a serious health risk to the public due to $\mathrm{Cd}$ uptake and translocation in agricultural crops ${ }^{3}$. The adverse health impacts of $\mathrm{Cd}$ exposure in population of the Mae Sot district have been reported in various studies. Reports indicate a high incidence of kidney disease among local populations, presumably resulting from consumption of agricultural crops cultivated on Cd-contaminated soil ${ }^{4}$.

Despite the extent of Cd-contamination in the Mae Sot district, little research has been conducted to identify a viable and cost-effective method to remediate local soils. Among the existing remedi- 
ation technologies, phytoremediation is considered an ecologically-friendly approach to treat metalcontaminated soil. The two primary phytoremediation strategies used to treat metal-affected soil are phytoextraction and phytostabilization ${ }^{5}$. The latter technology has gained significant attention in recent years by virtue of its success in various soil types, both upland and wetland. Phytostabilization is a well-established method for immobilizing metals in soil; extensive root systems sorb soil contaminants, thus preventing leaching or lateral migration. Plants in this strategy are termed 'excluders'. Plants enhance metal stabilization in the rhizosphere via the release of root exudates and by improving soil biological activity thus increasing organic carbon levels ${ }^{6}$. During phytostabilization soil structure is not disturbed and there are no hazardous byproducts ${ }^{7}$.

Phytostabilization is appropriate for long-term growth of timber for commercial purposes. However, proper selection of plants is critical in phytostabilization, as the species plays a key role with respect to the metal stabilizing potential of the root system and the quantity of vegetative cover for protection of soil from the effects of wind and water ${ }^{8}$. Excluder tree species used elsewhere include birch (Betula pendula), black locust (Robinia pseudoacacia), oak (Quercus robur, Q. petraea), Scots pine (Pinus sylvestris), and Douglas fir (Pseudotsuga menziesii) ${ }^{9}$. However, few reports exist regarding the utilization of excluder tree species in Thailand.

Eucalyptus (Eucalyptus spp.), a predominantly Australian native plant, consists of approximately 700 species. Plants of this genus provide substantial economic value for industrial markets via wood products and extraction of eucalyptus oil for pharmaceutical and medical markets ${ }^{10}$. Various species of eucalyptus have been investigated for their metal phytostabilization ability ${ }^{11,12}$. Eucalyptus camaldulensis is a moderately fast growing tree with high biomass production and wide adaptability to climatic and edaphic conditions. The species is well suited for plantation cultivation on degraded lands (e.g., waterlogged and saline soils) and helps improve soil quality ${ }^{13}$. Eucalyptus was found to accumulate low levels of heavy metals in various plant parts when compared to other species. Eucalyptus is rarely consumed by organisms, so any accumulated $\mathrm{Cd}$ has little risk of entering the food chain ${ }^{12}$. Hence this genus may serve as an effective phytostabilization agent in metal-enriched soils.

Although eucalyptus is an excluder of several heavy metals, soil amendments and/or fertilizer still must be added to contaminated soil to improve plant growth and enhance metal stabilization potential. Several organic soil amendments have been successfully used for phytotreatment of contaminated soil as they are non-toxic, inexpensive, and naturally degradable. Organic amendments such as animal manure and compost have been reported to enhance soil physical and chemical properties, ensure ecological biodiversity and decrease metal bioavailability ${ }^{14}$. The objective of this study was to evaluate the influence of organic amendments on phytostabilization of Cd-contaminated soil by E. camaldulensis via greenhouse and field experiments.

\section{MATERIALS AND METHODS}

\section{Physicochemical properties of Cd-contaminated} soil

The soils of interest were collected from agricultural fields, both Cd-contaminated and noncontaminated in the Mae Tao river basin, Mae Sot district, Tak province (N 16 $46^{\prime} 58.4^{\prime \prime}$ E $98^{\circ} 37^{\prime}$ $\left.65.1^{\prime \prime}\right)$. Soil material was collected from the surface $\left(<20 \mathrm{~cm}\right.$ depth) of plots measuring $12 \mathrm{~m}^{2}$. Both types of soil material (i.e., contaminated and noncontaminated) were collected from five locations (four corners and one central location) and composited in the field. Soil samples were brought to the laboratory and oven-dried at $70^{\circ} \mathrm{C}$ for $48 \mathrm{~h}$. Dried samples were ground with an agate mortar and pestle and subsequently sieved through a 2-mm mesh sieve. After sieving, samples were analysed for total Cd concentration using a flame atomic absorption spectrophotometer (FAAS; AAnalyst 200, PerkinElmer) after $\mathrm{HNO}_{3}$ digestion. Samples were tested for extractable Cd concentration using FAAS after extraction with $0.05 \mathrm{M}$ diethylene triamine pentaacetic acid (DTPA) ${ }^{15}$. Total nitrogen $(\mathrm{N})$ was determined using the Kjeldahl method. Extractable phosphorus (P) concentrations were measured using the Bray II method, and extractable potassium (K) using extraction with neutral $\mathrm{NH}_{4} \mathrm{OAc}$ buffered to $\mathrm{pH}$ 7.0. Soil cation exchange capacity was determined after leaching with $1 \mathrm{~N} \mathrm{NH}_{4} \mathrm{OAc}$ buffer. Organic matter content was measured using the Walkley-Black titration ${ }^{16}$. Soil $\mathrm{pH}$ was measured on a 1:5 (w/v) suspension of soil : deionized water using a glass electrode $\mathrm{pH}$ meter (Hanna instruments HI 221), and electrical conductivity (EC) using an EC meter (Hanna instruments HI 993310). Soil texture was determined using the hydrometer method $^{17}$. 


\section{Plant cultivation}

E. camaldulensis plants were germinated from seeds, grown in commercial soil material and placed in a greenhouse $\left(27-29^{\circ} \mathrm{C}, 70 \%\right.$ relative humidity, $17600 \mathrm{~lx}, 12 / 12 \mathrm{~h}$ photoperiod). After three months, healthy and homogenous plants $(30 \mathrm{~cm}$ height) were selected for further study.

\section{Greenhouse study}

The greenhouse study was conducted under the same conditions as described in the previous section. Two kilograms of soil material were placed into plastic pots $(20 \mathrm{~cm}$ diameter, $18 \mathrm{~cm}$ tall) fitted with a plastic screen at the base. All soil treatments were equilibrated following the method of Blaylock et $\mathrm{al}^{18}$, i.e., deionized (DI) water was applied to soil overnight until water holding capacity attained approximately $80 \%$. Healthy and uniform E. camaldulensis plants were transplanted into pots (one plant per pot). Treatment groups consisted of Cdcontaminated soil amended with cow manure, pig manure, and organic fertilizer $(10 \% \mathrm{w} / \mathrm{w})$. Cow and pig manure were obtained from lagoons on the university research farms. The organic fertilizer consisted of animal manures, plant debris, humic acid, and amino acids. The amendments were allowed to air-dry at $25^{\circ} \mathrm{C}$ for 1 month. The dried amendments were sieved through a 2-mm mesh sieve and then applied. The control group was Cd-contaminated soil alone. Five replicates were established for each treatment.

Plant pots were arranged in the greenhouse using a randomized complete block design. Pots were watered daily $(250 \mathrm{ml} / \mathrm{pot})$ and supplemented weekly with $100 \mathrm{ml}$ concentrated Hoagland's nutrient solution (low phosphate concentration; $0.01 \mathrm{mM} \mathrm{KH}_{2} \mathrm{PO}_{4}$ ). Two grams of organic amendment were added before planting and every other month. After three months all plants were harvested by carefully removing the entire plant from the pots, washed thoroughly with tap water to remove excess soil, and rinsed with DI water. Plants were subsequently separated into shoots and roots, and ovendried at $70^{\circ} \mathrm{C}$ for two days prior to determination of the dry weight.

\section{Field study}

The field study took place from February to October 2014. Total rainfall and average air temperature were $1429.8 \mathrm{~mm}$ and $27.3^{\circ} \mathrm{C}$, respectively. Plots measuring $3 \times 3 \mathrm{~m}$ were established; each plot had three rows containing nine plants with a spacing of $1 \mathrm{~m}^{2}$. Plots received either cow manure, pig manure, or organic fertilizer, or no treatment. Each treatment consisted of three replicates. Young plants were transplanted into the plots and covered by plastic nets to shade them against the intense summer sunlight. Prior to transplanting and every three months afterwards, $12 \mathrm{~g}$ of organic amendment was applied as a soil treatment. The amendments were incorporated to a $25-\mathrm{cm}$ depth with a steel shovel. All plots were watered daily using equal amounts of water $(500 \mathrm{ml}$ and 11 for the young and adult plants ( $>6 \mathrm{~m}$ ), respectively). At the end of the experiment, three plants were removed from each plot, thoroughly washed, and separated into shoots and roots. Plant tissue was oven-dried at $70^{\circ} \mathrm{C}$ for $48 \mathrm{~h}$ for subsequent chemical analysis.

\section{Plant growth performance}

At harvest, plant growth performance criteria including survival rate, growth rate, plant height and dry biomass production were determined. Survival rate is defined as the fraction of plants surviving per treatment during the experimental period, i.e., the number of remaining plants after the experiment divided by the total number of plants at the start of the experiment. Plant growth rate is a vital tool for remediation studies as it indicates the capability of plant to grow under stressed conditions ${ }^{19}$. Growth rate was calculated as $\left(\mathrm{DBP}_{\mathrm{a}}-\mathrm{DBP}_{\mathrm{i}}\right) / \Delta t$ or as $\left(H_{\mathrm{a}}-H_{\mathrm{i}}\right) / \Delta t$, where $\mathrm{DBP}_{\mathrm{a}}$ and $H_{\mathrm{a}}$ are the dry biomass and height for plants after harvesting, respectively, while $\mathrm{DBP}_{\mathrm{i}}$ and $H_{\mathrm{i}}$ are the dry biomass and height for plants before planting, and $\Delta t$ is the time interval before plant collection.

\section{Cd analysis in plant tissue and soil}

Dried plant material was ground with an IKA MF 10 basic microfine grinder drive, sieved through a 2-mm mesh sieve and weighed. Approximately $0.5 \mathrm{~g}$ of plant tissue was placed into a Pyrex test tube. Samples were acid digested using $70 \% \mathrm{HNO}_{3}$ and $37 \% \mathrm{HCl}$ in a microwave oven (ETHOS One; Milestone Inc.). Digested samples were analysed with either FAAS or a graphite furnace atomic absorption spectrophotometer (GF-AAS; AAnalyst 600, PerkinElmer), depending on metal concentration. Soil samples were digested in a microwave with concentrated $70 \% \mathrm{HNO}_{3}$ and $30 \% \mathrm{H}_{2} \mathrm{O}_{2}$. Cadmium concentrations in digested soil samples were determined using either FAAS or GF-AAS, depending on Cd concentration. 
Table 1 Selected physical and chemical properties of the soil before planting.

\begin{tabular}{lcccc}
\hline Parameter & Cd $^{*}$ & CdOrg & CdPig & CdCow \\
\hline pH & 7.2 & 7.4 & 7.7 & 7.3 \\
EC $(\mathrm{dS} / \mathrm{m})^{\dagger}$ & 0.20 & 0.34 & 0.48 & 0.39 \\
$\mathrm{CEC}(\mathrm{cmol} / \mathrm{kg})$ & 10.0 & 13.6 & 14.3 & 13.1 \\
$\mathrm{OM}(\mathrm{g} / \mathrm{kg})$ & 23.4 & 43.9 & 58.2 & 49.1 \\
$\mathrm{Total} \mathrm{N}^{\star}$ & 2823 & 3446 & 4943 & 3828 \\
Extractable $^{\star}$ & 10.0 & 6.0 & 14.0 & 12.0 \\
Extractable $^{\star}$ & 140.0 & 490.0 & 1030.0 & 710.0 \\
Total Cd $^{\star}$ & 19.6 & 19.4 & 19.5 & 19.5 \\
Extractable Cd $^{\star}$ & 3.6 & 5.1 & 5.8 & 5.9 \\
\hline
\end{tabular}

* Cd: Cd-contaminated soil (control); Org: organic fertilizer; Pig: pig manure; Cow: cow manure.

$\dagger$ EC: electrical conductivity; CEC: cation exchange capacity; OM: organic matter.

$*(\mathrm{mg} / \mathrm{kg})$

Analytical accuracy and precision for FAAS analysis were checked by running standard solutions after every 20 samples. $\mathrm{Cd}\left(\mathrm{NO}_{3}\right)_{2}$ (Merck) was used as the internal standard. A method blank and certified reference materials (NIST SRM 2710a Montana soil, and NIST SRM 1515 apple leaves, for soils and plants, respectively) were included for quality control.

\section{Data analysis for Cd uptake}

Metal uptake was calculated as $C \times \mathrm{DBP}$, where $C$ is the metal concentration in the plant part (shoot or root) and DBP is the dry biomass of plant. Metal uptake indicates metal concentration in the plant part which is sequestered by translocation processes ${ }^{11}$. The translocation factor (TF), which indicates the degree of metal movement within the plant ${ }^{20}$, was calculated as $\mathrm{TF}=C_{\text {shoot }} / C_{\text {root }}$, and the bioconcentration factor for the root (BCFR), which provides an indication of the root accumulation potential ${ }^{21}$, was calculated as BCFR $=C_{\text {root }} / C_{\text {soil }}^{*}$, where $C_{\text {soil }}^{*}$ is the metal-extractable concentration in the soil.

\section{Statistical analysis}

All data were analysed using SPSS 18.0. ANOVA was performed using least significant difference (LSD) post hoc comparisons, with $95 \%$ confidence level $(p<0.05)$.

\section{RESULTS}

\section{Properties of soil and amendments}

The contaminated soil had a neutral or slightly alkaline pH (range 7.2-7.7) (Table 1). Levels of plant-available $\mathrm{N}$, $\mathrm{P}$, and $\mathrm{K}$ were within acceptable
Table 2 Physicochemical properties of the amendments at the initiation of the study.

\begin{tabular}{lccc}
\hline Parameter & Org $^{*}$ & Pig & Cow \\
\hline pH & 8.1 & 8.3 & 8.2 \\
EC $(\mathrm{dS} / \mathrm{m})$ & 4.3 & 4.8 & 4.5 \\
$\mathrm{CEC}(\mathrm{cmol} / \mathrm{kg})$ & 34.8 & 41.2 & 37.9 \\
OM $(\mathrm{g} / \mathrm{kg})$ & 63.2 & 72.5 & 65.9 \\
Total N $(\mathrm{mg} / \mathrm{kg})$ & 4355 & 6323 & 5133 \\
Extractable P $(\mathrm{mg} / \mathrm{kg})$ & 23.3 & 43.4 & 34.3 \\
Extractable K $(\mathrm{mg} / \mathrm{kg})$ & 734.1 & 983.2 & 773.8 \\
Total Cd $(\mathrm{mg} / \mathrm{kg})$ & 0.2 & 0.2 & 0.1 \\
Extractable Cd $(\mathrm{mg} / \mathrm{kg})$ & $\mathrm{BDL}^{\dagger}$ & $\mathrm{BDL}$ & $\mathrm{BDL}$ \\
\hline
\end{tabular}

\footnotetext{
*Abbreviations as in Table 1.
}

$\dagger$ BDL: below detectable limit.

limits. Total and extractable soil Cd concentrations were 19.6 and $3.6 \mathrm{mg} / \mathrm{kg}$, respectively. Soil Cd concentrations in excess of about $1 \mathrm{mg} / \mathrm{kg}$ are considered to be evidence of anthropogenic pollution ${ }^{22}$. Soil texture was classified as loam.

All amendments contained medium to high levels of total N, extractable P and $\mathrm{K}$ (Table 2). The high extractable $\mathrm{P}$ values in the animal manure may be the result of elevated $\mathrm{P}$ concentrations in animal feed. Total Cd concentrations in all amendments were $<0.2 \mathrm{mg} / \mathrm{kg}$ (Table 2). Many organic and inorganic fertilizers have been found to contain toxic elements such as $\mathrm{Cd}, \mathrm{Pb}$, or As. The average $\mathrm{Cd}$ concentration in European fertilizers is $138 \mathrm{mg} / \mathrm{kg}^{23}$. Organic and inorganic P fertilizers have increased $\mathrm{Cd}$ concentrations in surface soil up to $300 \mathrm{mg} / \mathrm{kg}^{24}$. Hansen ${ }^{25}$ stated that average Cd levels in fertilized soil were $0.18-0.24 \mathrm{mg} / \mathrm{kg}$, depending on fertilizer type. Organic amendments are a main source of both macro- and micro-nutrients in agricultural soil, especially those used by farmers in developing countries; however, there is still no established regulatory Cd limit for organic amendments, particularly in animal manures. Thus it is desirable to ensure that organic fertilizers contain low $\mathrm{Cd}$ concentrations before plant cultivation.

The amended treatments had increased EC, CEC, OM and nutrient concentrations compared with Cd-contaminated soil (Table 3). Total and DTPA-extractable $\mathrm{Cd}$ concentrations were relatively low, but still exceeded the standard for noncontaminated soil ( $>3 \mathrm{mg} / \mathrm{kg}$ ); such levels are toxic to many plant species ${ }^{26}$. The DTPA-extractable Cd concentrations in all amended soils were slightly higher than that of the Cd-contaminated soil alone (Table 3).

After plant harvest in both greenhouse and 
Table 3 Total and DTPA extractable Cd concentration in soils of various treatments in greenhouse and field experiments, before and after plant harvest.

\begin{tabular}{|c|c|c|c|c|c|c|}
\hline \multirow[t]{2}{*}{ Soil } & \multicolumn{2}{|c|}{ Start } & \multicolumn{2}{|c|}{ Greenhouse } & \multicolumn{2}{|c|}{ Field } \\
\hline & Total & Extractable & Total & Extractable & Total & Extractable \\
\hline $\mathrm{Cd}$ & $19.6 \pm 2.4^{\mathrm{a}}$ & $5.6 \pm 0.4^{\mathrm{ab}}$ & $18.1 \pm 1.5^{\mathrm{a}}$ & $2.4 \pm 0.8^{\mathrm{ab}}$ & $19.0 \pm 1.3^{\mathrm{a}}$ & $6.0 \pm 0.5^{\mathrm{a}}$ \\
\hline CdOrg & $19.4 \pm 1.3^{\mathrm{a}}$ & $5.1 \pm 1.1^{\mathrm{a}}$ & $18.7 \pm 0.4^{\mathrm{a}}$ & $2.1 \pm 1.4^{\mathrm{a}}$ & $18.0 \pm 1.0^{\mathrm{a}}$ & $4.6 \pm 0.7^{a}$ \\
\hline CdPig & $19.5 \pm 1.1^{\mathrm{a}}$ & $5.8 \pm 1.2^{\mathrm{a}}$ & $18.7 \pm 1.3^{\mathrm{a}}$ & $1.9 \pm 0.8^{\mathrm{a}}$ & $18.7 \pm 1.5^{\mathrm{a}}$ & $5.3 \pm 0.6^{\mathrm{a}}$ \\
\hline CdCow & $19.5 \pm 0.6^{\mathrm{a}}$ & $5.9 \pm 1.4^{\mathrm{a}}$ & $18.1 \pm 1.4^{\mathrm{a}}$ & $2.3 \pm 0.3^{\mathrm{a}}$ & $8.9 \pm 1.8^{\mathrm{a}}$ & $5.3 \pm 0.3^{\mathrm{a}}$ \\
\hline
\end{tabular}

Data are mean \pm SD. Different letters within the same column show significant different data (LSD: $p<0.05$ )
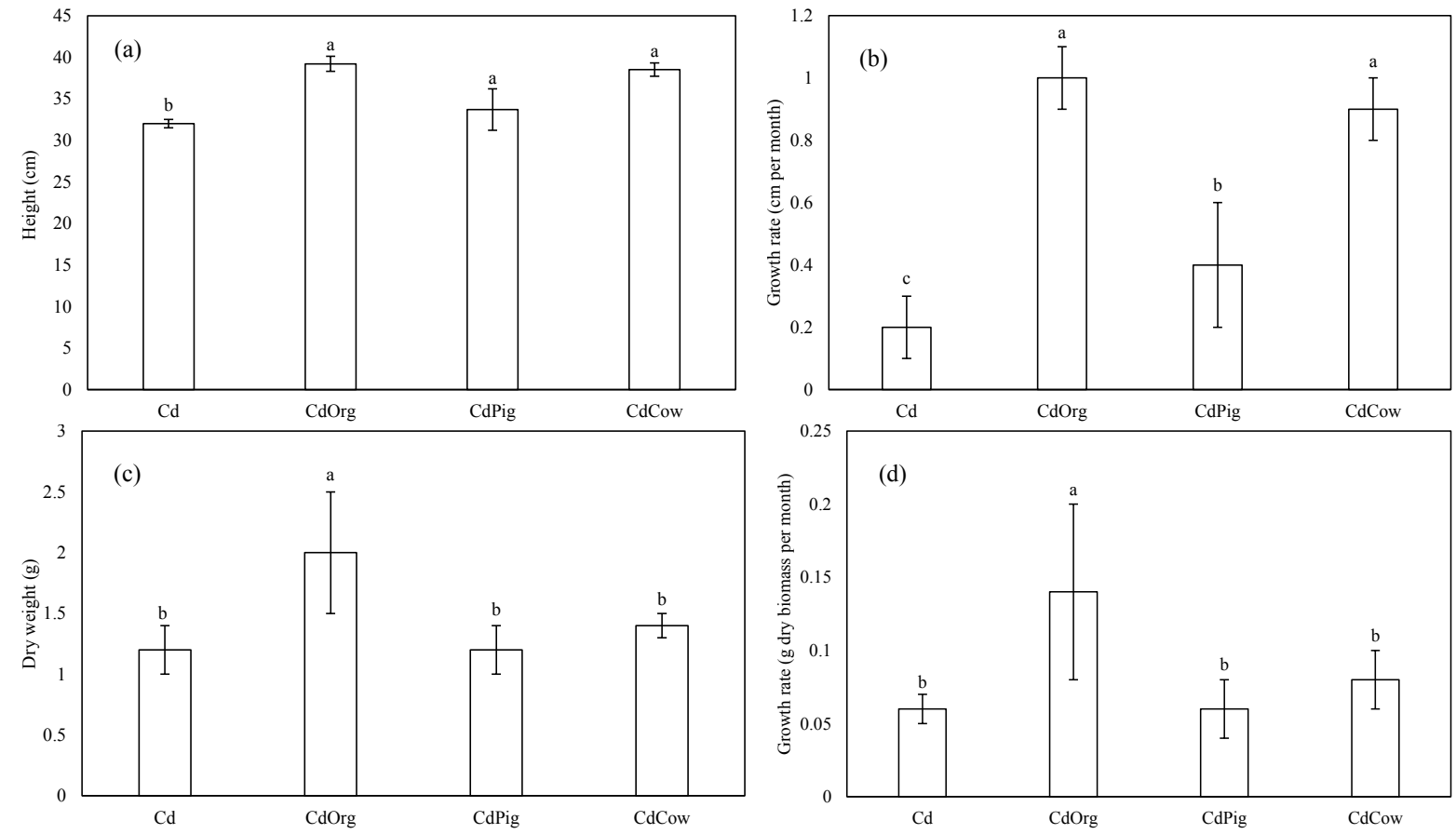

Fig. 1 Growth performance of E. camaldulensis in greenhouse experiment: (a) height; (b) growth rate in height; (c) dry biomass; (d) growth rate in dry biomass. Small letters show the difference between amendment effects (LSD: $p<0.05$ ).

field experiments, total and DTPA-extractable Cd concentrations in all amended treatments were not significantly different $(p>0.05)$ from those of nonamended soil, indicating that the organic amendments did not increase soil Cd solubility (Table 3).

\section{Plant growth performance}

All plants in both greenhouse and field experiments survived throughout the respective experimental periods (Fig. 1, Fig. 2) with no observable toxic effects. The amendments markedly increased plant growth in terms of total dry biomass and height $(p<0.05)$. Dry biomass production increased from $1.2 \mathrm{~g} /$ plant to $2.0 \mathrm{~g} /$ plant, and from $1.24 \mathrm{~kg} /$ plant to $3.34 \mathrm{~kg} /$ plant in the greenhouse and field studies, respectively. Without amendment supplementation, E. camaldulensis survived but total dry biomass production and height were lower than those in the amended treatments. The relative order of plant height for the greenhouse and field studies was CdOrg $\sim$ CdCow $>$ CdPig $>$ Cd and CdOrg $\sim$ CdPig $>$ CdCow $>\mathrm{Cd}$, respectively. The relative order for biomass production from both greenhouse and field studies was CdOrg $>$ CdCow $\sim \mathrm{CdPig}>\mathrm{Cd}$ (Fig. 1, Fig. 2).

\section{Cd accumulation and uptake}

Cadmium uptake and accumulation by E. camaldulensis showed similar trends in both greenhouse and field experiments. E. camaldulensis accumulated 

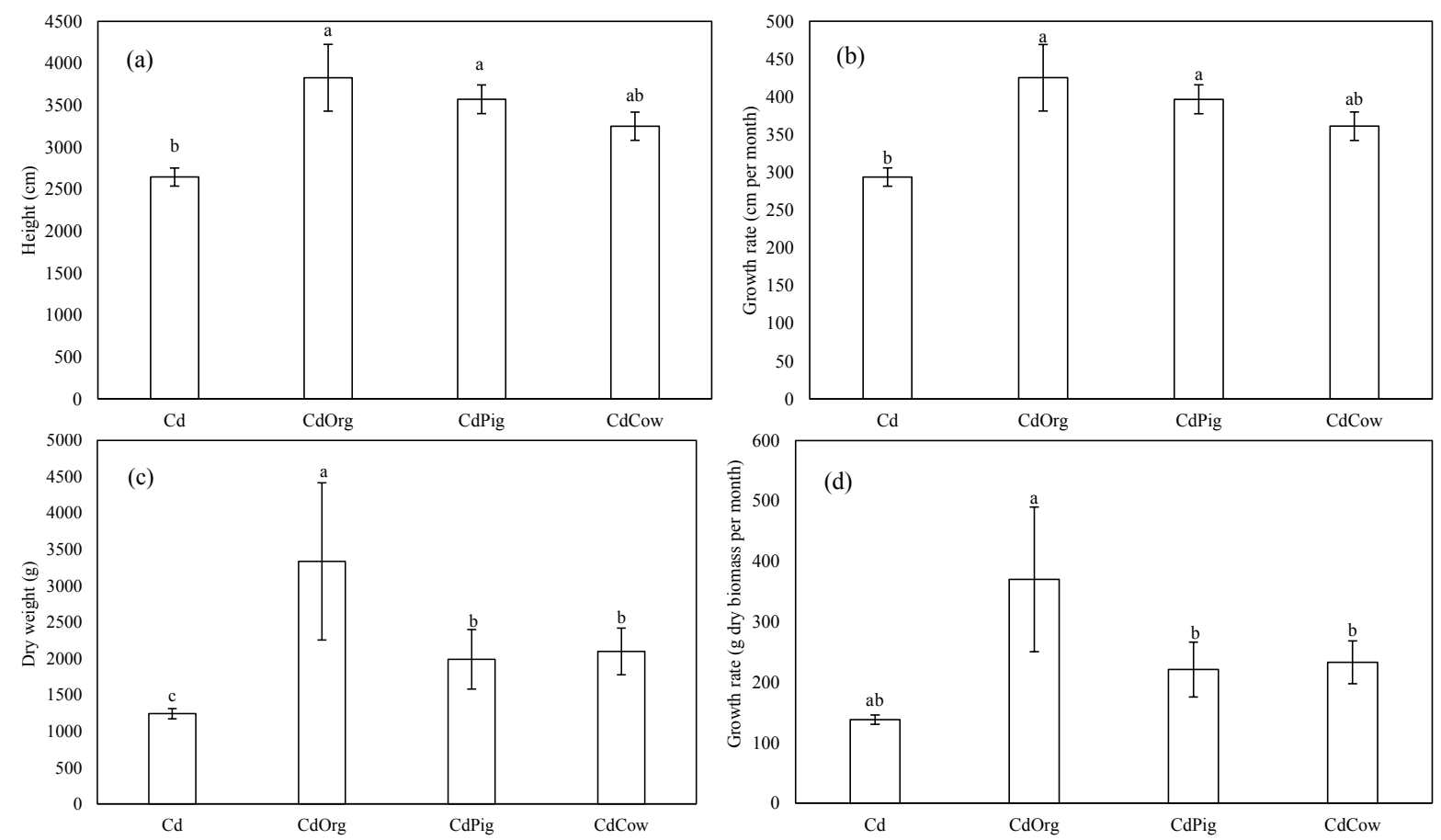

Fig. 2 Growth performance of E. camaldulensis in field experiment: (a) height; (b) growth rate in height; (c) dry biomass; (d) growth rate in dry biomass. Small letters showed differences between amendment effects (LSD: $p<0.05$ ).

Table 4 Dry biomass production (DBP), Cd accumulation (Cd-A), Cd uptake (Cd-U), translocation factor (TF) and bioconcentration factor of root (BCFR) of E. camaldulensis in greenhouse and field experiments for 3 and 9 months, respectively.

\begin{tabular}{|c|c|c|c|c|c|c|c|}
\hline & \multirow{2}{*}{$\begin{array}{c}\text { DBP } \\
\text { (g/plant) }\end{array}$} & \multicolumn{3}{|c|}{ Cd-A in plant $(\mathrm{mg} / \mathrm{kg})$} & \multirow{2}{*}{$\begin{array}{c}\text { Cd-U } \\
(\mu \mathrm{g} / \text { plant })\end{array}$} & \multirow[t]{2}{*}{$\mathrm{TF}$} & \multirow[t]{2}{*}{ BCFR } \\
\hline & & Shoot & Root & Whole plant & & & \\
\hline \multicolumn{8}{|c|}{ Greenhouse experiment } \\
\hline $\mathrm{Cd}$ & $1.2 \pm 0.2^{\mathrm{b}}$ & $0.6 \pm 0.1^{\mathrm{b}}$ & $1.3 \pm 0.3^{\mathrm{b}}$ & $0.8 \pm 0.2^{\mathrm{b}}$ & $1.0 \pm 0.1^{\mathrm{b}}$ & $0.2 \pm 0.0^{\mathrm{b}}$ & $2.3 \pm 0.6^{\mathrm{a}}$ \\
\hline CdOrg & $2.0 \pm 0.5^{\mathrm{a}}$ & $0.8 \pm 0.1^{\mathrm{b}}$ & $3.0 \pm 0.7^{\mathrm{a}}$ & $1.4 \pm 0.2^{\mathrm{a}}$ & $2.6 \pm 0.5^{\mathrm{a}}$ & $0.3 \pm 0.1^{\mathrm{b}}$ & $2.0 \pm 1.3^{\mathrm{a}}$ \\
\hline CdPig & $1.2 \pm 0.2^{\mathrm{b}}$ & $1.5 \pm 0.2^{\mathrm{a}}$ & $2.6 \pm 0.3^{\mathrm{ab}}$ & $1.6 \pm 0.4^{\mathrm{a}}$ & $2.0 \pm 0.6^{\mathrm{ab}}$ & $0.6 \pm 0.1^{\mathrm{a}}$ & $1.6 \pm 0.6^{\mathrm{b}}$ \\
\hline CdCow & $1.4 \pm 0.1^{\mathrm{ab}}$ & $0.7 \pm 0.2^{\mathrm{b}}$ & $4.0 \pm 0.4^{\mathrm{a}}$ & $1.8 \pm 0.4^{\mathrm{a}}$ & $2.7 \pm 0.8^{\mathrm{a}}$ & $0.2 \pm 0.1^{b}$ & $1.8 \pm 0.3^{\mathrm{a}}$ \\
\hline \multicolumn{8}{|c|}{ Field experiment } \\
\hline Cd & $1240 \pm 70^{c}$ & $11.4 \pm 3.1^{\mathrm{a}}$ & $21.8 \pm 4.3^{\mathrm{a}}$ & $14.5 \pm 1.7^{\mathrm{a}}$ & $18000 \pm 1200^{c}$ & $0.5 \pm 0.1^{\mathrm{b}}$ & $3.8 \pm 1.3^{\mathrm{a}}$ \\
\hline CdOrg & $3340 \pm 1080^{a}$ & $9.5 \pm 2.4^{\mathrm{a}}$ & $17.2 \pm 3.8^{\mathrm{bc}}$ & $11.6 \pm 1.6^{\mathrm{a}}$ & $38600 \pm 12100^{a}$ & $0.6 \pm 0.2^{\mathrm{b}}$ & $3.4 \pm 0.7^{b}$ \\
\hline CdPig & $1990 \pm 410^{\mathrm{b}}$ & $10.8 \pm 0.6^{\mathrm{a}}$ & $18.1 \pm 1.6^{\mathrm{bc}}$ & $12.1 \pm 2.2^{\mathrm{a}}$ & $24600 \pm 9400^{b}$ & $0.6 \pm 0.1^{\mathrm{a}}$ & $3.5 \pm 0.8^{\mathrm{ab}}$ \\
\hline CdCow & $2100 \pm 320^{b}$ & $9.9 \pm 1.0^{\mathrm{a}}$ & $17.6 \pm 1.0^{\mathrm{b}}$ & $11.4 \pm 2.5^{\mathrm{a}}$ & $23500 \pm 1200^{b}$ & $0.6 \pm 0.1^{\mathrm{b}}$ & $3.5 \pm 0.5^{\mathrm{ab}}$ \\
\hline
\end{tabular}

Data are mean \pm SD. Different letters within the same column show significant different data (LSD: $p<0.05$ )

higher Cd concentrations in roots compared with shoots. In the field experiment, addition of organic amendments resulted in increased Cd uptake in the order: CdOrg $>$ CdCow $\sim$ CdPig $>$ Cd (Table 4). All treatments exhibited BCFR values $>1$ (Table 4), indicating the potential of this species as an excluder. The highest BCFR values were determined in the Cd- contaminated soil alone. All TF values were smaller than 1 (Table 4).

Tissue Cd concentrations significantly increased with increase of exposure time $(p<0.05)$ i.e., there were greater tissue $\mathrm{Cd}$ levels in the field-grown plants ( 9 months) compared with the greenhousegrown plants (3 months). 


\section{DISCUSSION}

\section{Influence of organic amendments on plant growth and metal accumulation}

Many agricultural fields in the Mae Sot district of Thailand have experienced substantial contamination with $\mathrm{Cd}$; soil collected from fields for the current study contained $19.6 \mathrm{mg} / \mathrm{kg}$ total Cd. This concentration is categorized as moderate in terms of potential detrimental effects to plant growth on agricultural soil ${ }^{3}$. The organic amendment supplied are not expected to increase soil Cd content. Regardless, however, the soil contained adequate levels of plant nutrients. Furthermore, relevant soil physical and chemical properties (neutral $\mathrm{pH}$, acceptable levels of EC, CEC, OM) were sufficient to support plant growth.

Utilization of organic amendments is beneficial for soil health as it improves soil physicochemical properties. Organic sources can also reduce the dependency on costly commercial fertilizers by providing nutrients, both soluble and slow-release organic forms. Organic amendments can also modify the degree of heavy metal availability ${ }^{27}$.

In the reported study the addition of organic amendments (cow manure, pig manure, organic fertilizer) to Cd-contaminated soil resulted in slight increases in $\mathrm{pH}$ and total $\mathrm{N}$ concentration, moderate increases in EC, CEC, OM, and total P concentrations, and a marked increase in total $\mathrm{K}$ when compared to non-amended soil. Higher nitrogen content after organic amendment application, particularly in the organic fertilizer treatment, could help to increase plant growth, as the nitrogen is available in slow-release form ${ }^{28}$. Nitrogen is essential for protein formation and photosynthesis ${ }^{29}$. Soil $\mathrm{pH}$ values are considered appropriate for $E$. camaldulensis cultivation, whose recommended $\mathrm{pH}$ ranges from $4.0-8.5^{30}$. Plant nutrient availability is maximal at near-neutral $\mathrm{pH}$ values, and metal toxicity is mini$\mathrm{mal}^{31}$. It has been documented that these $\mathrm{pH}$ values can improve plant growth performance and increase sorption of metal cations, resulting in low mobility of metals and metalloids in contaminated soil ${ }^{32}$. EC values were addressed because all samples possessed EC values $>0.2 \mathrm{dS} / \mathrm{m}$ which exceeds the normal standard soil range ${ }^{33}$; furthermore, values $\geqslant 1.4 \mathrm{dS} / \mathrm{m}$ may impair root development, decreasing plant growth and yields ${ }^{33}$. In the reported study, however, E. camaldulensis retained normal growth under the elevated EC values $(0.3-0.5 \mathrm{dS} / \mathrm{m})$.

E. camaldulensis grown in amended soil exhibited improved growth performance, as demon- strated by plant height and dry biomass, compared with plants grown in non-amended soil. Organic fertilizer was the most effective amendment, resulting in the highest growth rates in both greenhouse and field experiments, followed by cow manure and pig manure. The results are in good agreement with previous studies which showed that organic fertilizer increased vegetative growth and biomass production $^{14,34}$. The OM present in the organic manure or fertilizer provides sources of slow-release nutrients, while at the same time increases the soil buffering capacity for acidity, cations, and water ${ }^{35}$. Besides acting as nutrient sources for plants, organic amendments also reduce metal toxicity by decreasing bioavailability of heavy metals ${ }^{27}$.

Different soil organic amendments including compost, sewage sludge, animal manures, and organic fertilizer have been used for phytoremediation of heavy metal-contaminated soil ${ }^{36}$. Most studies have demonstrated that organic amendments having a high humified OM content decrease bioavailability of metals in soil via adsorption and formation of stable complexes with humic substances ${ }^{37}$. Application of organic amendments did not result in a significant decrease of extractable Cd concentrations in the greenhouse and field studies. There was however a significant decrease in $\mathrm{Cd}$ accumulation in E. camaldulensis grown in organicamended soil after 9 months. The order of $\mathrm{Cd}$ uptake was CdOrg $>$ CdCow $\sim$ CdPig $>$ Cd. It has been suggested that increasing yields have resulted in decreased $\mathrm{Cd}$ concentrations in plants because of a dilution effect caused by plant growth rates exceeding the ability of plants to acquire $\mathrm{Cd}^{38}$.

The reported study demonstrates that organic fertilizer was the most effective amendment in increasing biomass of $E$. camaldulensis grown in $\mathrm{Cd}-$ contaminated soil. Similar findings were reported for Acacia mangium and Vetiver zizanioides grown in $\mathrm{Pb}$-contaminated mine tailings ${ }^{11,29}$. Much evidence indicates that soil microbial activity in organic fertilizers enhances organic matter decomposition, resulting in increased availability of plant nutrients $^{39}$. Organic fertilizers are used worldwide by virtue of their benefits to soil physical and chemical properties, low cost, and easy field application.

\section{Suitability for phytostabilization}

The desirable features of plant species selected for phytostabilization are tolerance to high concentrations of contaminants, the ability to develop an extensive root system, accumulation of pollutants in non-edible underground parts, low maintenance 
requirements, relatively high transpiration rates, relatively long growing period or ability for selfpropagation, and adaptation to local climate ${ }^{40}$. E. camaldulensis possesses most of these attributes. In the present study, E. camaldulensis grew well in contaminated soil, indicating its Cd tolerance. The plant has an extensive root system, is fast-growing, and produces substantial biomass. It accumulates Cd mainly in the roots and limits Cd translocation from roots to shoots ( $\mathrm{TF}<1$ ), thereby limiting the distribution of $\mathrm{Cd}$ into the food chain. The plant high BCFR values reflect its ability to uptake $\mathrm{Cd}$. Thus the higher BCFR and Cd uptake values in the field, compared with those in the greenhouse, might be due to the higher growth rate of plants under field conditions.

\section{CONCLUSIONS}

E. camaldulensis shows significant potential for phytostabilization of Cd-contaminated soil. The plant is tolerant of high soil Cd concentrations and accumulated little $\mathrm{Cd}$ in aboveground biomass. All organic amendments, particularly organic fertilizer, were effective in enhancing plant growth. The organic fertilizer treatment resulted in a TF $<1$ and a BCFR $>$ 1 , indicating the potential of this species to stabilize $\mathrm{Cd}$ in the roots. Plants grown on amended soils had lower $\mathrm{Cd}$ accumulation compared to those grown on the Cd soil alone. Eucalyptus, even though indigenous to Australia, is widely cultivated worldwide because of its rapid growth, broad adaptability, and low maintenance requirements, in addition to the demand for wood products and oils. The plant is useful for commercial purposes such as paper and furniture industries; cultivation of this species can be successfully carried out on metal-enriched soil.

Acknowledgements: This work was supported by a grant from Mahidol University.

\section{REFERENCES}

1. Järup L (2003) Hazards of heavy metal contamination. Br Med Bull 68, 167-82.

2. Gonick HC (2008) Nephrotoxicity of cadmium and lead. Indian J Med Res 128, 335-52.

3. Simmons RW, Pongsakul P, Saiyasitpanich D, Klinphoklap S (2005) Elevated levels of cadmium and zinc in paddy soils and elevated levels of cadmium in rice grain downstream of a zinc mineralized area in Thailand: implication for public health. Environ Geochem Health 27, 501-11.

4. Swaddiwudhipong W, Limpatanachote P, Mahasakpan P, Krintratun S, Punta B, Funkhiew T (2012)
Progress in cadmium-related health effects in persons with high environmental exposure in northwestern Thailand: a five-year follow-up. Environ Res 112, 194-8.

5. Bolan NS, Park JH, Robinson B, Naidu R, Huh K (2011) Phytostabilization: a green approach to contaminant containment. Adv Agron 112, 145-204.

6. Pilson-Smits E (2005) Phytoremediation. Annu Rev Plant Biol 56, 15-39.

7. Ruttens A, Vangronsveld J, Boisson J, Pottecher G, Jacquemin P (2005) Metal/metalloid immobilization and phytostabilization of contaminated sites: Theoretical background and field application at an As contaminated former goldmine site. In: Difpolmine Conference, 8th July 2005, Budapest, Hungary [lecture].

8. Pulford LD, Watson C (2003) Phytoremediation of heavy metal contaminated land by trees-a review. Environ Int 29, 529-40.

9. Van Nevel L, Mertens J, Staelens J, De Schrijver A, Tack FMG, De Neve S, Meers E, Verheyen K (2011) Elevated Cd and Zn uptake by aspen limits the phytostabilization potential compared to five other tree species. Ecol Eng 37, 1072-80.

10. Batish DR, Singh HP, Kohli RK, Kaur S (2008) Eucalyptus essential oil as a natural pesticide. Forest Ecol Manag 256, 2166-74.

11. Meeinkuirt W, Pokethitiyook P, Kruatrachue M, Tanhan P, Chaiyarat R (2012) Phytostabilization of a Pbcontaminated mine tailing by various tree species in pot and field trial experiments. Int $J$ Phytoremediat 14, 925-38.

12. King DJ, Doronila AI, Feenstra C, Baker AJM, Woodrow IE (2008) Phytostabilization of arsenical gold mine tailings using four Eucalyptus species: growth, arsenic uptake and availability after five years. Sci Total Environ 406, 35-42.

13. Bhati G, Singh G (2003) Growth and mineral accumulation in Eucalyptus camaldulensis seedlings irrigated with mixed industrial effluents. Bioresour Tech 88, 221-8.

14. Montiel-Rozas M, Madejó E, Madejó P (2015) Evaluation of phytostabilizer ability of three ruderal plants in mining soils restored by application of organic amendments. Ecol Eng 83, 431-6.

15. American Public Health Association, American Water Works Association, Water Environment Federation (2005) Standard Methods for the Examination of Water and Wastewater, APHA, Washington, DC.

16. Sparks DL (1996) Methods of Soil Analysis, Soil Science Society of America, Wisconsin.

17. Allen SE, Grimshaw HM, Parkinson HM, Quarmby JA (1974) Chemical Analysis of Ecological Materials, Blackwell, Oxford.

18. Blaylock MJ, Salt DE, Dushenkov S, Zakharova O, Gussman C, Kapulnik Y (1977) Enhanced accumulation of $\mathrm{Pb}$ in Indian mustard by soil-applied chelating 
agents. Environ Sci Tech 31, 860-5.

19. Rotkittikhun P, Chaiyarat R, Kruatrachue M, Pokethitiyook P, Baker AJM (2007) Growth and lead accumulation by the grasses Vetiveria zizanioides and Thysanolaena maxima in lead-contaminated soil amended with pig manure and fertilizer: a glasshouse study. Chemosphere 66, 45-53.

20. Zu YQ, Li Y, Chen JJ, Chen HY, Qin L, Schvartz C (2005) Hyperaccumulation of $\mathrm{Pb}, \mathrm{Zn}$, and $\mathrm{Cd}$ in herbaceous grown on lead-zinc mining area in Yunnan, China. Environ Int 31, 755-62.

21. Zou T, Li T, Zhang X, Yu H, Huang H (2012) Lead accumulation and phytostabilization potential of dominant plant species growing in a lead-zinc mine tailing. Environ Earth Sci 65, 621-30.

22. Uminska R (1993) Cadmium contents of cultivated soils exposed to contamination in Poland. Environ Geochem Health 15, 15-9.

23. Davister A (1996) Studies and research on processes for the elimination of cadmium from phosphoric acid. In: OECD Proceedings-Fertilizers as a Source of Cadmium, Inter-Organization Programme for the Sound Management of Chemicals (IOMC), Paris, pp 21-30.

24. Grant CA (2011) Influence of phosphate fertilizer on cadmium in agricultural soils and crops. Pedologist 54, 143-55.

25. Hansen OC (2000) Cadmium in Fertilizers, The Danish Environmental Protection Agency, Copenhagen.

26. Alloway BJ (1995) Heavy Metals in Soils, Chapman \& Hall, London, U.K.

27. Tordoff GM, Baker AJM, Willis AJ (2000) Current approaches to the revegetation and reclamation of metalliferous mine wastes. Chemosphere 41, 219-28.

28. Bolan NS, Duraisamy VP (2003) Role of inorganic and organic soil amendments on immobilization and phytoavailability of heavy metals: a review involving specific case studies. Aust J Soil Res 41, 533-55.

29. Meeinkuirt W, Kruatrachue M, Tanhan P, Chaiyarat R, Pokethitiyook P (2013) Phytostabilization potential of $\mathrm{Pb}$ mine tailings by two grass species, Thysanolaena maxima and Vetiveria zizanioides. Water Air Soil Pollut 224, 1750-61.

30. Mickelbart MV, Lee B, Camberato JJ, Stanton KM (2012) Commercial Greenhouse and Nursery Production: Soil pH, Purdue Extension publ. HO-240-W, Purdue Univ, West Lafayette, IN.

31. Harris JA, Birch P, Palmer JP (1996) Land Restoration and Reclamation, Longman, London, U.K.

32. Violante A, Cozzolino V, Perelomov L, Caporale AG, Pigna M (2010) Mobility and bioavailability of heavy metals and metalloids in soil environments. $J$ Soil Sci Plant Nutr 10, 268-92.

33. Shu WS, Ye ZH, Lan CY, Zhang ZQ, Wong MH (2001) Acidification of lead/zinc mine tailings and its effect on heavy metal mobility. Environ Int 26, 389-94.

34. Mohapatra SC, Das TK (2009) Integrated effect of biofertilizers and organic manure on turmeric (Curcuma longa). Environ Ecol 27, 1444-5.

35. de Ridder N, van Keulen H (1990) Some aspects of the role of organic matter in sustainable intensified arable farming systems in the West-African semi-aridtropics (SAT). Fertil Res 26, 299-310.

36. Sabir M, Zia-ur-Rehman M, Hakeem MS, Saifullah (2015) Phytoremediation of metal-contaminated soils using organic amendments: Prospects and challenges. In: Hakeem KR, Sabir M, Ozturk M, Murmut A (eds) Soil Remediation and Plants, Academic Press, London, pp 503-23.

37. Shuman LM (1999) Organic waste amendments effect on zinc fractions of two soils. J Environ Qual 28, 1442-7.

38. Jarrell WM, Beverly RB (1981) The dilution effect in plant nutrition studies. Adv Agron 34, 197-224.

39. Lazcano C, Gómez-Brandón M, Revilla P, Domínguez $\mathrm{J}$ (2013) Short-term effects of organic and inorganic fertilizers on soil microbial community structure and function. Biol Fertil Soils 49, 723-33.

40. Vangronsveld J, Cunningham SD (1998) Introduction to the concepts. In: Vangronsveld J, Cunningham SD (eds) Metal-Contaminated Soils: In Situ Inactivation and Phytorestoration, Springer, Berlin, pp 1-15. 